possibilities arising from his work and not to rest content with publishing his results in a scientific journal. The method of recruiting men of science also encourages contact between scientific workers and the general public, while the whole educational system, as well as the use made of the Press and the influence of the trade unions. is directed to the development of a scientific attitude to life. A brief account of this aspect of education in the U.S.S.R. is contained in a further article "Preparing a Scientific Nation" by Beatrice King in the same number, while Dr. C. Norris, under the title "Experimental Medicine in the U.S.S.R.", describes some of the results achieved in medical research.

\section{Telephone and Telegraph Statistics of the World}

IN Electrical Communication of July 1940, tables are given of the telephone and telegraph statistics of the world compiled by the American Telephone and Telegraph Company. The tables are compiled for the year ending January 1, 1939. The amount of telephone and telegraph wire in use in this period is also given. Except in the case of the United States and Canada, the telegraph service is operated by Governments. In the United States the number of miles of telephone line operated predominantly by private companies is nearly 93 million, and Canada comes next in the North American group with 5.4 million operated by private and Government concerns. In South America, the Argentine comes first with 1.58 million miles and Brazil second with $1 \cdot 13$ million miles, both privately worked. In Europe, Germany comes first with 18.0 million miles, and Great Britain and Northern Ireland jointly second with $15 \cdot 2$ million miles, both worked by Government. In Asia, Japan comes first with 4.8 million miles Government operated, and China is second with 0.8 million miles run by private companies and Government. In Africa, the Union of South Africa comes first with 0.83 million miles and Egypt is second with 0.47 million miles, and finally in Oceania Australia comes first with $2 \cdot 83$ million miles and New Zealand second with 0.11 million miles, all of which are operated by Government.

If we consider the percentage of telephone wire in operation possessed by the whole world, the United States possesses $53 \cdot 2$ per cent, Germany comes second with $10 \cdot 3$ per cent and Great Britain third with 8.7 per cent. Discussing the percentage of telephone line in the whole world possessed by a country per 100 of the population, it is stated that the United States comes an easy first with 71.5 per cent, Sweden is second with $49 \cdot 2$ and Canada third with $48 \cdot 2$. The total lengths of telegraph line possessed by each country run in the following order : United States $2 \cdot 3$ million miles, Russia $0 \cdot 8$ million miles and British India $0 \cdot 37$ million miles.

\section{Oxford Electric Supply Undertaking}

Mr. H. G. Fraser, the city electrical engineer of Oxford and manager of the electrical undertaking, can now claim for Oxford the second position among the records of the lists showing the number of units sold per head of the population relating to the authorized undertakings in Great Britain. According to the Electrical Times of October 3, the two main reasons why the revenue and units sold per head of the population exceeded all previous records of the undertaking were the connecting up of the heating installation of the New Bodleian Library during the early part of the summer, and the incidence of exceptionally severe weather conditions during the last quarter of the year. These two factors outweighed the general slump consequent upon the outbreak of war and the black-out. More than four million more units were sold for private lighting, heating and cooking, and this brought the total to 34 millions. This represents 563 units sold per head of the population. The surplus at $£ 23,910$ shows an improvement of $£ 8,316$.

\section{Seismological Data from India}

THE Seismological Bulletin of the India and Ceylon seismological observatories for the period JulySeptember 1939 has just been received. It has been published by the Government of India Meteorological Department under the direction of Dr. C. W. B. Normand. An average of eleven slight shocks and tremors daily was registered during July. It was estimated at the Colaba Observatory at Bombay that the earthquakes of July 12, 18, and 20 occurred near New Guinea, south of the Nicobar Islands and in the Pacific Ocean west of the Tonga Deep respectively. The latter probably had a depth of focus near $680 \mathrm{~km}$. During August an average of ten earthquakes daily was recorded. The epicentre of the one on August 8 was in the ocean to the south-west of Ceylon, according to Colaba. It was felt over a large part of Ceylon.

The earthquake of August 25 was felt in New Guinea at Rabaul and Kokopo. During September an average of seventeen shocks was recorded, the one on September 8 being the greatest in the three months. It occurred in the Aleutian Islands though on the same day there was another shock to the south of Sumatra. According to Colaba, the shock of September 6 was in Afghanistan, and the ones of September 14, 19, 22, and 25, in the sea to the south-east of the Andaman Islands, to the south-east of Lake Aral, near Smyrna, and near the Nicobar Islands respectively. Macroseismic reports from voluntary observers mention eleven earthquakes and several tremors. The greatest of these, at Dhubri, had intensity 6 on the Rossi-Forel scale on August 21, other shocks being recorded from Drosh (3), Gauhati (2), Yatung, Tibet (2+ several tremors), Chaman and Dalhousie.

\section{The Colombo Museum}

SINCE Sir William Gregory in 1872 developed the idea of collecting exhibits illustrating the natural history, antiquities and industrial products of Ceylon, the Colombo Museum has preserved a high scientific standard while at the same time offering a centre of interest to the large number of people which visit its collections $(334,528$ in 1939). Although many influences have led to the preponderance of natural 